\title{
Tahap Perencanaan dan Implementasi Dalam Proses Keperawatan
}

\author{
Adisty Olyvia Hutagalung
}

adistyhutagalung@gmail.com

\section{Latar Belakang}

Proses profesionalisme dalam keperawatan telah dimulai sejak dicetuskannya keperawatan sebagai profesi yang mandiri pada Lokakarya Nasional tahun 1983 dan masih berlangsung sampai saat ini. Serta didukung berkembangnya system pendidikan keperawatan dengan adanya program Pasca sarjana dan program spesialis keperawatan.

Seorang perawat professional harapannya menjadi seorang perawat yang menampilkan aktifitas keperawatan sesuai kode etik profesi dalam perannya yang memiliki ciri berorientasi pada pelayanan masyarakat, dengan menggunakan metode proses keperawatan. Perawatan sebagai bagian dari pemberi layanan kesehatan, yaitu memberi asuhan keperawatan dengan menggunakan proses keperawatan akan selalu dituntut untuk berfikir kritis dalam berbagai situasi.

Proses keperawatan adalah suatu cara atau metode yang sistematis dalam memberikan asuhan keperawatan yang dilakukan oleh perawat dan bekerjasama dengan pasien (individu, keluarga, masyarakat) yang bertujuan untuk mengidentifikasi masalah keperawatan dengan melakukan pengkajian, menentukan diagnosa, merencanakan tindakan yang akan dilakukan, melaksanakan tindakan serta mengevaluasi hasil asuhan keperawatan yang telah diberikan dengan berfokus pada pasien, berorientasi pada tujuan yang telah ditetapkan bersama.

Menurut Craven dan Hirnle bahwa proses keperawatan memiliki enam fase yaitu: pengkajian, diagnosa, tujuan, rencana tindakan, implementasi, dan evaluasi. Orientasi dari pelayanan asuhan keperawatan adalah pada pencapaian tujuan asuhan keperawatan. Asuhan keperawatan baru dapat dikatakan berhasil dan selesai jika semua tujuan asuhan keperawatan yang telah ditetapkan dalam perencanaan keperawatan telah tercapai.

Perencanaan dan implementasi merupakan bagian yang sangat penting dalam proses keperawatan. Tahap ini merupakan tahap dimana tindakan keperawatan direncanakan dan akan dilaksanakan. Sifat proses keperawatan harus berkesinambungan dan jika kinerja perawat kurang optimal seperti ini maka akan merugikan klien karena proses pemulihan pasien akan 
terhambat dan masa perawatan akan menjadi panjang yang berdampak pada pembayaran biaya perawatan yang cukup besar. Oleh karena itu, dilakukan penelitian mengenai perencanaan dan implementasi proses keperawatan.

\section{Metode}

Metode yang digunakan adalah literature review. Kajian literature meninjau literatur ilmiah tentang sebuah topik dan secara kritis menganalisis, mengevaluasi, dan menyintesis temuan penelitian, teori, dan praktik. Pencarian artikel penelitian menggunakan jurnal, tesis, skripsi, disertasi, artikel dan lainnya dengan menggunakan kata kunci yaitu dasar perencanaan, implementasi, proses keperawatan, asuhan keperawatan, konsep dasar keperawatan. Kriteria inklusi yaitu artikel full text yang berbahasa Inggris atau berbahasa Indonesia dipublikasikan dengan tahun paling lama 2012. Jumlah keseluruhan artikel yang didapatkan dilakukan penyaringan sesuai dengan kriteria inklusi sehingga hasil akhir ditemukan minimal 10 artikel yang di review.

\section{Hasil}

Pelayanan keperawatan merupakan bagian integral dari pelayanan kesehatan yang bisa menjadi tolak ukur keberhasilan dalam pencapaian tujuan suatu rumah sakit. Kualitas pelayanan keperawatan berjalan dengan baik apabila proses keperawatan yang dilaksanakan terstruktur dengan baik (Farlinda, 2011).

Asuhan keperawatan merupakan proses atau rangkaian kegiatan pada praktik keperawatan yang diberikan secara langsung kepada klien pasien di berbagai tatanan pelayanan kesehatan. Dilaksanakan berdasarkan kaidah-kaidah keperawatan sebagai suatu profesi yang berdasarkan ilmu dan kiat keperawatan, bersifat humanistik ,dan berdasarkan pada kebutuhan objektif klien untuk mengatasi masalah yang dihadapi klien.

Proses keperawatan diperkenalkan pada tahun 1950-an sebagai proses yang terdiri atas tiga tahap : Pengkajian, perencanaan dan evaluasi yang didasarkan pada metode ilmiah pengamatan, pengukuran, pengumpulan data dan penganalisaan temuan. Kajian selama bertahun-tahun, penggunaan dan perbaikan telah mengarahkan perawat pada pengembangan proses keperawatan menjadi lima langkah yang konkret (pengkajian, identifikasi masalah, perencanaan, implementasi dan evaluasi) yang memberikan metode efisien tentang pengorganisasian proses berfikir untuk pembuatan keputusan klinis 
Dalam Jurnal Ilmiah Kesehatan (2019) Idealnya, perencanaan asuhan keperawatan bersifat individualistik dan responsif terhadap kebutuhan unik pasien. Tujuannya adalah menyusun strategi untuk mengatasi hambatan atau masalah pasien. Perawat secara teratur meninjau kemajuan pasien dan merevisi rencana perawatan yang sesuai kebutuhan pasien.

Dalam Jurnal Kesehatan MANARANG (2016) Implementasi adalah pengelolaan dan perwujudan dari rencana keperawatan yang telah di susun pada tahap perencanaan. Ukuran intervensi keperawatan yang diberikan kepada klien terkait dengan dukungan, pengobatan, tindakan untuk memperbaiki kondisi, pendidikan untuk klien-keluarga, atau tindakan untuk mencegah masalah kesehatan yang muncul dikemudian hari. Untuk kesuksesan pelaksanaan implementasi keperawatan agar sesuai dengan rencana keperawatan, perawat harus mempunyai kemampuan kognitif (intelektual), kemampuan dalam hubungan interpersonal, dan keterampilan dalam melakukan tindakan. Proses pelaksanaan implementasi harus berpusat kepada kebutuhan klien, faktor-faktor lain yang mempengaruhi kebutuhan keperawatan.

\section{Pembahasan}

\section{Perencanaan Keperawatan}

Perencanaan adalah pengembangan strategi desain untuk mencegah, mengurangi, dan mengatasi masalah-masalah yang telah diidentifikasi dalam diagnosis keperawatan. Perencanaan keperawatan adalah suatu rangkaian kegiatan penentuan langkah-langkah pemecahan masalah dan prioritasnya, perumusan tujuan, rencana tindakan dan penilaian asuhan keperawatan pada pasien/klien berdasarkan analisis data dan diagnosa keperawatan. Desain perencanaan menggambarkan sejauh mana mampu menetapkan cara menyelesaikan masalah dengan efektif dan efisien.

Tujuan dokumentasi perencanaan keperawatan keperawatan adalah:

1. Untuk mengidentifikasi fokus keperawatan kepada klien atau kelompok

2. Untuk membedakan tanggungjawab perawat dengan profesi kesehatan lainnya

3. Untuk menyediakan suatu kriteria guna pengulangan dan evaluasi Keperawatan

4. Untuk menyediakan kriteria klasifikasi klien

5. Menyediakan suatu pedoman dalam penulisan.

Tipe Rencana Tindakan Keperawatan terdiri dari:

1) Diagnostik/Obserevasi

Rencana tindakan keperawatan diagnostik adalah rencana tindakan untuk mengkaji atau melakukan observasi terhadap kemajuan klien dengan pemantauan 
secara langsung yang dilakukan secara kontinu. Dengan observasi ini, diharapkan halhal yang ditetapkan dalam kriteria hasil dapat dipantau secara berkesinambungan sampai tujuan berhasil dicapai.

2) Terapeutik/Nursing Treatment

Rencana tindakan keperawatan terapeutik adalah rencana tindakan yang ditetapkan untuk mengurangi, memperbaiki dan mencegah perluasan masalah. Rencana tindakan ini berupa intervensi mandiri yang bersumber dari ilmu, kiat dan seni keperawatan. Dalam suatu masalah keperawatan, biasa didapatkan beberapa (lebih dari satu) alternatif penyelesaian masalahnya, perawat dituntut untuk dapat memilih mana yang paling sesuai untuk ditetapkan pada pasien.

3) Penyuluhan /Health Education/Pendidikan Kesehatan

Rencana tindakan keperawatan yang berbentuk pendidikan kesehatan adalah rencana tindakan yang ditetapkan bertujuan untuk meningkatkan perawatan diri kilen dengan penekanan pada partisispasi klien untuk betanggung jawab terhadap perawatan diri, terutama untuk perawatan dirumah. Penyuluhan atau pendidikan kesehatan diperlukan, terutama bila masalah keperawatan dan kriteria hasil berhubungan dengan aspek kognitif, afektif, dan psikomotor. Penyuluhan yang dilakukan dapat berbentuk penyuluhan umum tentang segala sesuatu tentang penyakit dan perawatan klien atau juga lebih spesifik sesuai dengan masalah yang terjadi.

4) Rujukan atau Kolaborasi atau Medical Treatment

Rencana tindakan keperawatan kolaboratif adalah tindakan medis yang dilimpahkan kepada perawat. Rencana kolaboratif ini disesuaikan dengan masalah yang terjadi. Masalah yang bersifat kognitif, afektif dan psikomotor mungkin tidak memerlukan tindakan medis. Namun, untuk masalah yang berhubungan dengan perubahan fungsi tubuh, sering memerlukan rencana kolaboratif. Sifat rencana tindakan kolaboratif ini merupakan tugas perawat.

Dalam membuat rencana keperawatan, ada beberapa hal yang perlu untuk diperhatikan sebagai berikut:

Tahap 1: Menentukan Prioritas Masalah.

Prioritas masalah merupakan upaya perawat untuk mengidentifikasi respons pasien terhadap masalah kesehatannya, baik aktual maupun potensial. Untuk menetapkan prioritas masalah seringkali digunakan hierarki kebutuhan dasar manusia. Pada kenyataannya perawat tidak mampu menyelesaikan permasalahan pasien secara 
bersamaan, oleh karena itu diperlukan upaya untuk memprioritaskan masalah. Prioritas diagnosa dibedakan dengan diagnosa yang penting sebagai berikut:

- Prioritas diagnosa merupakan diagnosa keperawatan, jika tidak diatasi saat ini akan berdampak buruk terhadap kondisi status fungsi kesehatan pasien.

- Diagnosa penting adalah diagnosa atau masalah kolaboratif dimana intervensi dapat di tunda tanpa mempengaruhi status fungsi kesehatan pasien.

- Hierarki yang biasa dijadikan dasar untuk menetapkan prioritas masalah adalah hirarki Maslow; kegawatan masalah kesehatan berupa ancaman kesehatan maupun ancaman kehidupan; tingkat masalah berdasarkan aktual, risiko, potensial dan sejahtera sampai sindrom; keinginan pasien.

Tahap 2: Menentukan Tujuan dan Kriteria Hasil (outcome).

Membuat tujuan berarti membuat standar atau ukuran yang digunakan untuk melakukan evaluasi terhadap perkembangan pasien dan keterampilan dalam merawat pasien. Tujuan keperawatan yang baik adalah pernyataan yang menjelaskan suatu tindakan yang dapat diukur berdasarkan kemampuan dan kewenangan perawat. Karena kriteria hasil diagnosa keperawatan mewakili status kesehatan pasien yang dapat dicapai atau dipertahankan melalui rencana tindakan keperawatan yang mandiri, sehingga dapat membedakan antara diagnosa keperawatan dan masalah kolaboratif. Hasil dari diagnosa keperawatan tidak dapat membantu mengevaluasi efektivitas intervensi keperawatan jika tindakan medis juga diperlukan.

a. Tujuan Perawatan berdasarkan SMART yaitu:

1) S: Spesific(tidak memberikan makna ganda)

2) M: Measurable (dapat diukur, dilihat, didengar, diraba, dirasakan ataupun dibantu)

3) A: Achievable (secara realistis dapat dicapai)

4) R: Reasonable (dapat dipertanggung jawabkan secara ilmiah)

5) T: Time (punya batasan waktu yang sesuai dengan kondisi klien).

Contoh: Setelah dilakukan asuhan keperawatan selama 1 x 24 jam, masalah gangguan rasa nyaman: nyeri dapat teratasi.

b. Kriteria Hasil

Karakteristik kriteria hasil yang perlu mendapatkan perhatian adalah:

1) Berhubungan dengan tujuan perawatan yang telah ditetapkan

2) Dapat dicapai

3) Spesifik, nyata dan dapat diukur 
4) Menuliskan kata positif

5) Menentukan waktu

6) Menggunakan kata kerja

7) Hindari penggunaan kata-kata 'normal, baik', tetapi dituliskan hasil batas ukuran yang ditetapkan atau sesuai.

Contoh: Capillary refill kurang dari 2 detik.

Tahap 3: Rencana Tindakan Keperawatan (nursing order)

Rencana tindakan yang akan diberikan pada pasien ditulis secara spesifik, jelas dan dapat di ukur. Rencana perawatan dibuat selaras dengan rencana medis, sehingga saling melengkapi dalam meningkatkan status kesehatan pasien. Dalam merumuskan rencana tindakan yang perlu diperhatikan adalah:

1. Rencana tindakan keperawatan merupakan desain spesifik intervensi yang membantu klien mencapai kriteria hasil

2. Dokumentasi rencana tindakan yang telah diimplementasikan harus ditulis dalam sebuah format agar dapat membantu perawat untuk memproses informasi yang didapatkan selama tahap pengkaian dan diagnosa keperawatan

3. Perencanaan bersifat indivisual sesuai dengan kondisi dan kebutuhan pasien

4. Bekerjasama dengan pasien dalam merencanakan intervensi.

Komponen dalam penulisan rencana tindakan keperawatan harus meliputi: komponen pertama waktu yang ditetapkan (tanggal dan jam), kedua Verb (kata kerja) dalam kalimat instruksi, ketiga Subjek yaitu siapa yang menerima tindakan keperawatan, keempat hasil merupakan hasil akhir yang dituju dari tindakan keperawatan. Kelima, target waktu merupakan periode ketika perawat melaksanakan instruksi keperawatan dan yang terakhir tanda tangan perawat.

Karakteristik dokumentasi Rencana Tindakan Keperawatan terdiri dari: ditulis oleh perawat profesional, dilaksanakan setelah kontak pertama dengan pasien, tempat strategis, Informasi baru.

2. Implementasi

Implementasi keperawatan adalah serangkaian kegiatan yang dilakukan oleh perawat untuk membantu pasien dari masalah status kesehatan yang dihadapi ke status kesehatan yang baik yang menggambarkan kriteria hasil yang diharapkan. Proses pelaksanaan implementasi harus berpusat kepada kebutuhan klien, faktor-faktor lain yang mempengaruhi kebutuhan keperawatan, strategi implementasi keperawatan, dan kegiatan komunikasi. 
Dalam pelaksanaannya terdapat tiga jenis implementasi keperawatan, yaitu:

1. Independent Implementations

Adalah implementasi yang diprakarsai sendiri oleh perawat untuk membantu pasien dalam mengatasi masalahnya sesuai dengan kebutuhan, misalnya: membantu dalam memenuhi activity daily living (ADL), memberikan perawatan diri, mengatur posisi tidur, menciptakan lingkungan yang terapeutik, memberikan dorongan motivasi, pemenuhan kebutuhan psiko-sosio-kultural, dan lain-lain.

2. Interdependen/Collaborative Implementations

Adalah tindakan keperawatan atas dasar kerjasama sesama tim keperawatan atau dengan tim kesehatan lainnya, seperti dokter. Contohnya dalam hal pemberian obat oral, obat injeksi, infus, kateter urin, naso gastric tube (NGT), dan lain-lain.

3. Dependent Implementations

Adalah tindakan keperawatan atas dasar rujukan dari profesi lain, seperti ahli gizi, physiotherapies, psikolog dan sebagainya, misalnya dalam hal: pemberian nutrisi pada pasien sesuai dengan diit yang telah dibuat oleh ahli gizi, latihan fisik (mobilisasi fisik) sesuai dengan anjuran dari bagian fisioterapi.

Beberapa pedoman atau prinsip dalam pelaksanaan implementasi keperawatan adalah sebagai berikut:

1. Berdasarkan respons pasien

2. Berdasarkan ilmu pengetahuan, hasil penelitian keperawatan, standar pelayanan profesional, hukum dan kode etik keperawatan

3. Berdasarkan penggunaan sumber-sumber yang tersedia

4. Sesuai dengan tanggung jawab dan tanggung gugat profesi keperawatan

5. Mengerti dengan jelas pesanan-pesanan yang ada dalam rencana intervensi keperawatan

6. Harus dapat menciptakan adaptasi dengan pasien sebagai individu dalam upaya meningkatkan peran serta untuk merawat diri sendiri (self care)

7. Menekankan pada aspek pencegahan dan upaya peningkatan status kesehatan.

8. Menjaga rasa aman, harga diri dan melindungi pasien

9. Memberikan pendidikan, dukungan dan bantuan

10. Bersifat holistik

11. Kerjasama dengan profesi lain

12. Melakukan dokumentasi 


\section{Penutup}

Proses asuhan keperawatan merupakan tugas dan kewajiban seorang perawat dari pasien datang sampai pasien pulang, dimulai dengan pengkajian secara menyeluruh, kemudian menegakkan diagnosa keperawatan dari data pengkajian tersebut, serta melaksanakan intervensi, implementasi dan evaluasi keefektifan diagnosa awal yang sudah ditegakkan. Perencanaan dan implementasi merupakan bagian yang sangat penting dalam proses keperawatan. Tahap ini merupakan tahap dimana tindakan keperawatan direncanakan dan akan dilaksanakan.

Perencanaan keperawatan adalah suatu rangkaian kegiatan penentuan langkah-langkah pemecahan masalah dan prioritasnya, perumusan tujuan, rencana tindakan dan penilaian asuhan keperawatan pada pasien/klien berdasarkan analisis data dan diagnosa keperawatan. Kemudian tindakan selanjutnya adalah implementasi keperawatan. Implementasi keperawatan adalah serangkaian kegiatan yang dilakukan oleh perawat untuk membantu pasien dari masalah status kesehatan yang dihadapi ke status kesehatan yang baik yang menggambarkan kriteria hasil yang diharapkan.

\section{Daftar Pustaka}

Budiono. 2016. Modul Bahan Ajar Cetak Keperawatan : Konsep Dasar Keperawatan. Jakarta : Pusdik SDM Kesehatan

Mulyanti, Y., Dinarti. 2017. Bahan Ajar Keperawatan : Dokumentasi Keperawatan. Jakarta : Pusdik SDM Kesehatan

Indriatie. 2013. Berpikir Kritis Dalam Proses Keperawatan. Jurnal Keperawatan, 4 (2), 89-93 Maria Terok, dkk. 2015. Hubungan Kinerja Perawat Pelaksana Dengan Penerapan Proses Keperawatan Di Irina C BLU RSUP Prof Dr.R.D.Kandou Manado. JUIPERDO, 4 (1), 55-60

Christina, P., Indracahyani, A. Yatnikasaria, A. 2019. Analisis Ketidaksinambungan Dokumentasi Perencanaan Asuhan Keperawatan : Metode Ishikawa. Jurnal Ilmiah Kesehatan, $12(11), 518-524$

Supratti., Ashriady. 2016. Pendokumentasian Standar Asuhan Keperawatan Di Rumah Sakit Umum Daerah Mamuju, Indonesia. Jurnal Kesehatan MANARANG, 2 (1), 44-51 
Mangole, J. E., Rompas, S., Ismanto, A. Y., 2015. Hubungan Perilaku Perawat Dengan Pendokumentasian Asuhan Keperawatan Di Cardiovaskular And Brain Center RSUP Prof. Dr. R. D. Kandou Manado. E-journal Keperawatan (e-Kp), 3 (2), 1-9

Kasim, M., Abdurrouf, M. 2016. Peningkatan Kualitas Pelayanan Dan Pendokumentasian Asuhan Keperawatan Dengan Metode Tim. NurseLine Journal, 1 (1), 62-72

Astar, F., Tamsah, H., Kadir, I. 2018. Pengaruh Pelayanan Asuhan Keperawatan Terhadap Kepuasan Pasien Di Puskesmas Takalala Kabupaten Soppeng. MIRAI : JOURNAL OF MANAGEMENT, 1 (2), 33-57

Wulandini, S., Krianto, T., Priwahyuni, Y. 2016. Faktor-Faktor Yang Berhubungan Dengan Pendokumentasian Asuhan Keperawatan Di Rumah Sakit Jiwa. NERS JURNAL KEPERAWATAN, 12 (2), 131-142

Butar-Butar, J., \& Simamora, R. H. (2016). Hubungan Mutu Pelayanan Keperawatan dengan Tingkat Kepuasan Pasien Rawat Inap di RSUD Pandan Kabupaten Tapanuli Tengah. Jurnal Ners Indonesia, 6(1), 50-63.

Simamora, R. H. (2005). Hubungan Persepsi Perawat Pelaksana Terhadap Penerapan Fungsi Pengorganisasian Yang Dilakukan Oleh Kepala Ruangan Dengan Kinerjanya Diruang Rawat Inap RSUD Koja Jakarta Utara (Doctoral dissertation, Tesis FIK UI, Tidak dipublikasikan). 